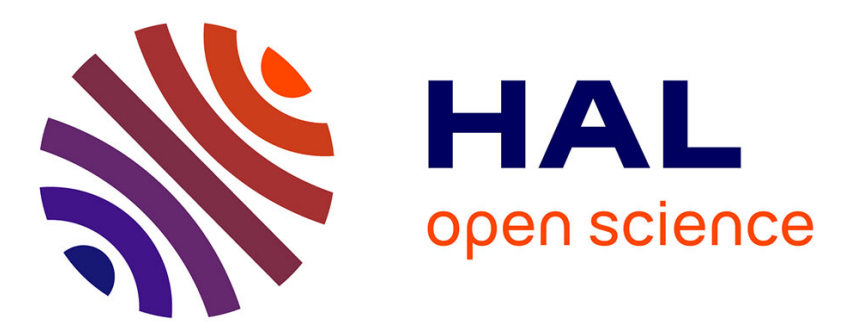

\title{
Lean After Sales Service - An Opportunity for OEMs to Ensure Profits
}

\author{
Uwe Dombrowski, Constantin Malorny
}

\section{To cite this version:}

Uwe Dombrowski, Constantin Malorny. Lean After Sales Service - An Opportunity for OEMs to Ensure Profits. IFIP International Conference on Advances in Production Management Systems (APMS), Sep 2014, Ajaccio, France. pp.618-625, 10.1007/978-3-662-44736-9_75 . hal-01387942

\section{HAL Id: hal-01387942 \\ https://hal.inria.fr/hal-01387942}

Submitted on 26 Oct 2016

HAL is a multi-disciplinary open access archive for the deposit and dissemination of scientific research documents, whether they are published or not. The documents may come from teaching and research institutions in France or abroad, or from public or private research centers.
L'archive ouverte pluridisciplinaire HAL, est destinée au dépôt et à la diffusion de documents scientifiques de niveau recherche, publiés ou non, émanant des établissements d'enseignement et de recherche français ou étrangers, des laboratoires publics ou privés.

\section{(c)(1)}

Distributed under a Creative Commons Attribution| 4.0 International License 


\title{
Lean After Sales Service - An opportunity for OEMs to ensure profits.
}

\author{
Univ.-Prof. Dr.-Ing. Uwe Dombrowski, Dipl.-Wirtsch.-Ing. Constantin Malorny \\ Institute for Advanced Industrial Management, Technische Universität Braunschweig, \\ Langer Kamp 19, 38106 Braunschweig, Germany
}

\begin{abstract}
Original equipment manufacturers (OEM) have recently recognized that offering after sales services enables higher revenues and profits (for example additional services, spare parts or accessories business). For this reason, OEMs have decided to step up efforts to improve or offer additional after sales services in order to achieve competitive advantages. Moreover, offering after sales services combined with primary products is an appropriate instrument to improve customer satisfaction and loyalty. Due to the increasing competitive pressure in the after sales service sector, methods and instruments have to be identified to sustain a profitable business area. In branch of production, the use of lean production systems turned out as a suitable application to secure and improve competitiveness, to reduce waste in production and to realize sustainable profits. Therefore, in this paper a methodical approach to transfer lean production system (LPS) principles to customer service as well as a qualitative applicability of the principles will be described. For transferring LPS principle to customer service, the reference guideline "VDI 2870 - Lean production systems” published by The Association of German Engineers is used.
\end{abstract}

Keywords: Lean Production Systems, Lean After Sales Service, Customer Service

\section{Introduction}

This paper focuses on customer service as one part of the after sales service whereas customer service is understood as support of the primary products [1]. Spare part management, another field of the after sales service, is especially associated with logistics, forecasts, demands and manufacturing. In this field of after sales service a lot of research activities has been performed including approaches of lean logistics but the transfer of lean principles to customer service or even the development of an lean after sales services system focusing on customer service has not been researched sufficiently yet.

To ensure the high profits resulting from after sales service (particularly the customer service), in this paper a guideline for transferring lean production system principles to service is presented. With the help of a lean after sales service-guideline, services can be improved and help to satisfy customers. As a result, lean after sales

adfa, p. 1, 2011.

(C) Springer-Verlag Berlin Heidelberg 2011 
service improves the customer's feedback with regard to used services and therefore helps to strengthen customer loyalty and promote primary product sales [2].

\section{After Sales Service}

Manufacturing enterprises have recently recognized that there is a huge economic potential of offering after sales services in addition to their primary products [3]. This is recognizable by the high number of $60 \%$ of manufacturing companies offering services and supports combined with goods in western countries [4]. These services have become a very successful sector of Original Equipment Manufacturers (OEM) because of being mainly responsible for the gained profits. Companies are able to generate more than $65 \%$ of overall profits by offering services complementary to primary products. Beyond this, it is possible to realize EBIT margins over $10 \%$. On the contrary, the spare part business, former driver of after sales service, is dealing with declining revenues and profits. [5]

These profits can be generated not only when selling but also during the complete life cycle. But the major advantage of after sales services over primary product sales is the low influence of economic cycles and economic crises. [6] Nevertheless, customer service sector deals with similar problems like the production sector. Customer's expectation is rising so that the quality of services has to be improved by the companies. But offered services still have to be cheaper than comparable offers. This results in revenue and competitive pressure. [7] Above this, customer loyalty as well as customer satisfaction has huge influence on revenues gained by OEM's after sales services which results in the improvement of the offered services [8].

Typically, offered services of OEMs are repair and spare part installation, commissioning, preventive maintenance, inspection, 24-hours-service-contracts, warranty and complaint management, modernization or upgrade of products and staff trainings [9], [10]. This listing demonstrates that the customer service has several different areas of responsibility. In addition, OEMs are also faced with the problem that services are difficult to standardize as well as customize [11]. Combined with an increasing number of variants of offered services and growth of service ranges [12], companies have to implement quality insurance as well as quality improvement sections reducing the profits and profitability [11].

\section{$3 \quad$ Lean production systems principle in service}

For realizing a lean enterprise, business units such as development, production and sales \& service need an implementation of lean principles [13]. Therefore, the guideline "lean production system" was created. Furthermore, principles taken from this guideline focusing on production and assembly were transferred to development [14]. Other units like sales \& service still need a transformation or a guideline for implementing lean production system principles.

Lean production systems have their origin in lean production, Taylorism and innovative working arrangements [15]. LPS constitute a methodical guideline for enter- 
prises with the aim to focus all production processes on the customer. Furthermore, lean production systems strive for waste reduction and continuous improvement so that LPS-implementation can help to generate profits sustainably. [16] To improve quality and increase transparency in production processes, LPS offer several principles, methods and tools. By implementing an individual developed production system companies are able to adapt and react to new market situations, customer expectations or challenging market conditions. Moreover, processes are transparent and it is possible to manufacture customer individual products high-qualitatively. [17] Typical principles implemented in lean production systems are standardization, zero defects principle, flow principle, pull principle, continuous improvement process, employee orientation and management by objectives, avoidance of waste and visual management [16], also explained and described in context of Toyota Production System respectively Lean Production.

The described objectives of lean production systems cover the same problem areas occurring in after sales services. Customers expect an excellent, individual service as well as individual support during operation of the product. At the same time, customers focus on cheap service performances, otherwise they change to a competitive service provider only specialized on offering services. To react to these customer requirements waste in service processes has to be reduced, service quality has to be improved and service delivery has to be adapted to the customer. [11] Therefore, the hypothesis is based on the assumption that lean production system principles are transferable to after sales service. By realizing this transfer, lean production system principles provide an opportunity to meet these challenges and customer requirements.

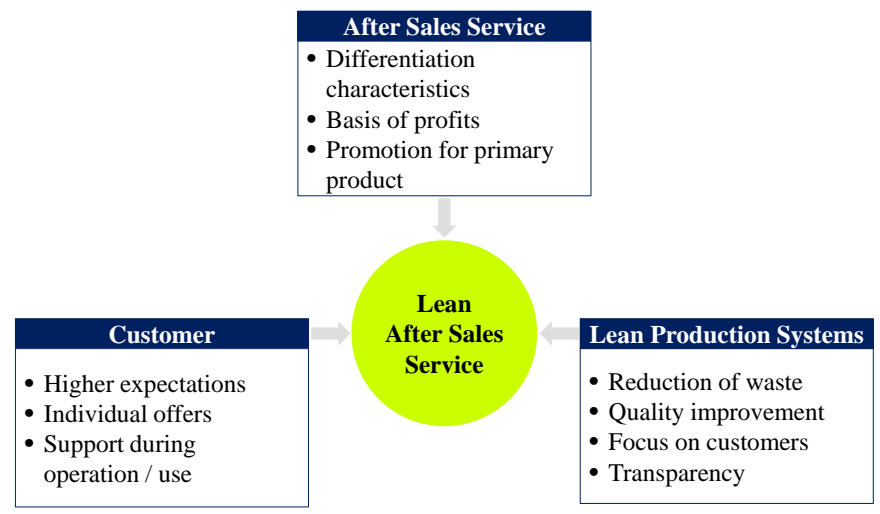

Fig. 1. Lean After Sales Systems

First approaches show that it is possible to transfer LPS-principles to service sector [18]. For example, in financial or insurance sector the use of these principles and methods is practicable because of a high number of similar processes and activities. Other fields of lean application are food service sector [7], hospitals [19] or administration (e.g. controlling or accounting). These sectors include a high number of static processes which are characterized by high repetition rates and low diversity so that processes can be standardized and a flow of information or material is realizable. [20] 


\section{Transferring LPS principles to customer service}

As already described, LPS-principles are not only suitable for production but also for service sector. Therefore, in this section a methodical transfer of the LPS principles is presented including identification of relevant influence factors, analysis and structuring of possible LPS principles. Moreover, individual adjustment and integration into daily routine are briefly described.

\subsection{Identification of relevant influence factors and basic conditions in service}

The need of the customer has to be identified so that all processes in customer service can be aligned to their requirements [7]. Here, every field of customer service includes own influence factors. For example, customers expect a fast repair of their products, e.g. their cars, and short waiting times at the repair station reception. In case of maintenance of machine tools, the down time has to be minimized and the maintenance process has to be designed effectively.

On service provider side, an analysis of business processes has to be performed to overview all relevant service activities. For example, process mapping or value stream mapping are applicable methods to represent all processes and connection between units or employees in a transparent way. With regard to high numbers of different tasks, varying lead times and fluctuating demand, problems in service processes can be identified. These processes and service-individual challenges build a cluster of influence factors concerning the customer service. On this basis, it is possible to identify possible LPS principles that can be transferred.

\subsection{Analysis of possible use of lean production system principles}

The identification of influence factors and basic condition is necessary for transferring LPS principles to customer service. It is possible that identified principles are not directly adaptable for each after sales service field. This is based on wide range of service variants (e.g. huge number of different repairs) including varying lead times and uncertain demand characteristics [21]. But generally, the implementation of LPS principles is possible. In particular, the principles standardization and continuous improvement possess high potential for an implementation in customer service. [12]

However, as mentioned before, standardization is appropriate for repetitive processes especially taking placing in flow production. These repetitive processes can be found in administrative tasks of the customer service. Therefore, the implementation of standardization in administration or common tasks [22] is noncritical and an effective principle. On the contrary, operational processes differ widely in effort, unspecified and indeterminable lead time and work content. As result, standards either have to be created for every work step leading to an enormous high number of different standards or standards have to be created flexibly to cover all work contents.

An adjustment of a LPS principle takes place for the principle "avoidance of waste". Some kinds of waste, such as overproduction, unnecessary movements or transportation [23], mainly occur in mass production but are unusual in service pro- 
cesses. As a result, these kinds of waste have to be modified. For example, "overproduction" could be modified to "too much information", "inefficient work routines" replaces unnecessary movements and transportation in service is represented by "information transfer". "Too much information" in service means that employees get information that is not needed or may confuse them whereas "inefficient work routines” is caused by high level of bureaucracy, unstructured work places or inefficient workshop layouts. Waste in "information transfer" describes non-expedient or slow information flows between employees or departments.

Generally, the principle "continuous improvement process" is directly adaptable. This principle represents the philosophy of simple but steady improvement of processes without high investments for new equipment. To implement this philosophy, a change of employee's mindset is required aiming to improve all process and routines. [24] Moreover, the implementation of key figures systems is necessary to verify improvements and to improve the quality of processes [25]. This philosophy as well as key figure systems are also appropriate and usable in service but the employees have to accept and live this principle. A qualitative evaluation of the possible use of lean production system principle described in VDI 2870 [16] is shown in figure 2.

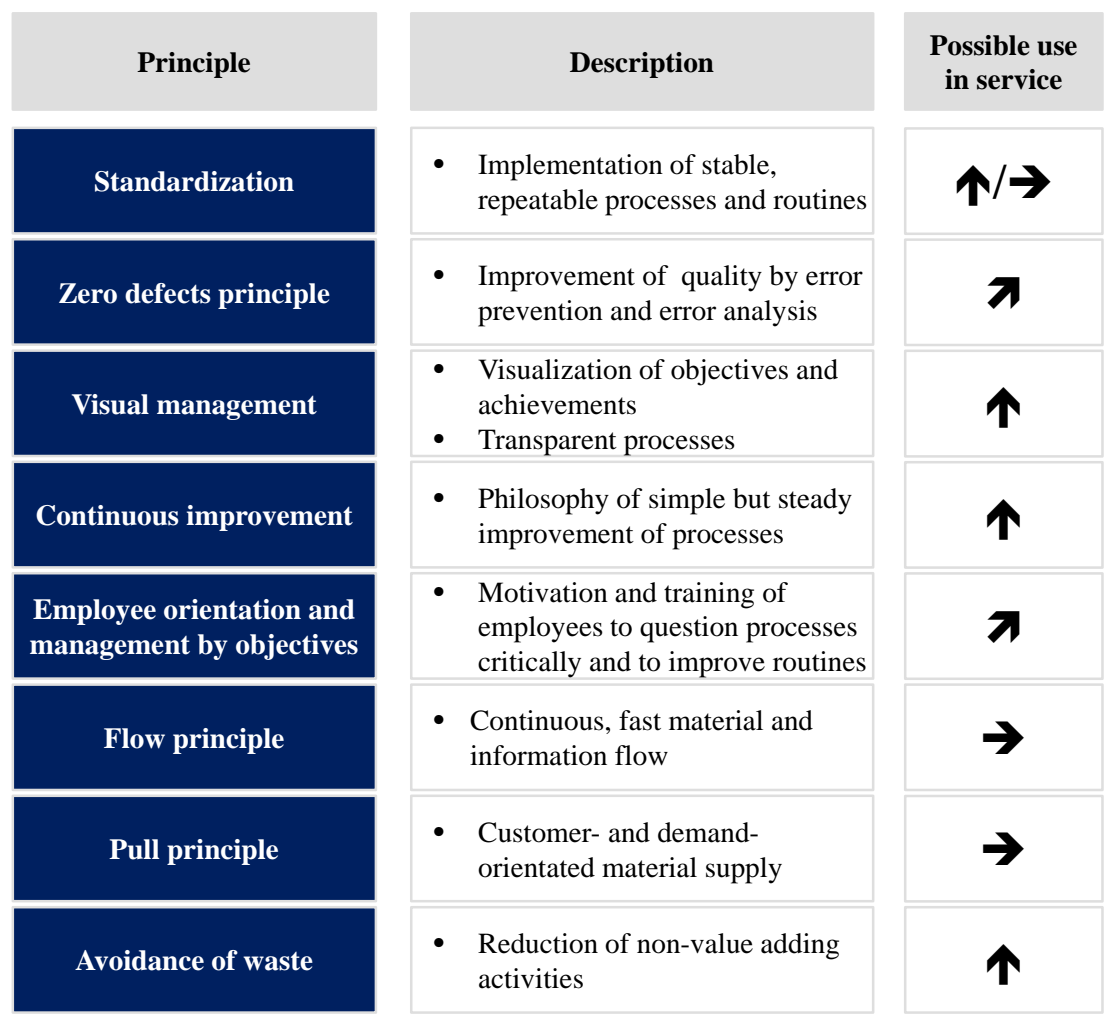

Fig. 2. Qualitative evaluation of possible use of LPS principle in customer service 
"VDI 2870 - Lean Production systems" is used because this reference guideline focuses on producing companies that are attempting to implement an individual lean production system. For this reason, all essential principles are identified as well as fields of application are explained so that this guideline constitutes a good basis for the analysis of a possible use in customer service.

For the identification and adjustment of further, appropriate principles, a comparison between each principle as well as its methods and the relevant influence factors or basic conditions is needed. All useful principles and methods are needed in the next step for structuring a valid guideline.

\subsection{Structuring a holistic guideline}

The structuring of the guideline can be created, analogous to VDI 2870 [16], as a principle catalogue. For each principle several methods and tools have to be listed which are necessary for implementing a lean after sales service. For realizing this step, there are two ways of creating the guideline: either providing one principle catalogue for each field of customer service or providing a single principle catalogue for all fields of customer service including individual information about possible fields of application and necessary adjustments of the principle, method and tool. This catalogue builds a basis for OEMs to select and implement principles depending on their individual conditions. After structuring possible principle an allocation of appropriate methods and tools is needed. At this stage changes or modification of methods and tools to the specifics of after sales service can be necessary as well. In accordance with lean production systems, the developed lean after sales service system is only a guideline listing possible principles but the individual implementation and integration into daily routine requires individual adjustment.

\subsection{Individual adjustment and integration into daily routine}

With the help of the developed guideline a company-individual implementation of principles can be performed. It is also possible to eliminate all non-value activities and processes so that the quality of the process will be improved. Moreover, the processes and activities will be created more customer-related as well as transparent. As result of lean after sales services, customer satisfaction and loyalty can be increased and OEMs are able to react faster to changing conditions.

To identify further company-specific influence factors, the execution of customer surveys helps to overview customer expectation. Above this, the implementation of complaint management continuously provides information regarding changing customer's wishes such as pricing of service or further service offers. Additionally, SWOT-analyses give information about strengths, weaknesses, opportunities and threats of the provided services. Based on weaknesses, opportunities and threats, problem fields can be identified and necessary principles can be selected.

Above this, the continuous improvement process is fundamental for lean after sales service systems. This process is based on the fact that operational employees have profound knowledge about the processes performing every day [24]. Thus, these em- 
ployees know best what kind of problems and errors in service process occur. With their help, inefficient processes or routines can be easily identified and fixed. Additionally, the implementation and tracking of key performance indicator systems helps to secure and improve service process quality.

\section{Summary}

The present paper deals with the transfer of lean production principles to after sales services. Therefore, the customer service as one field of after sales service is described. To transfer principles as well as methods and tools of lean production systems, an introduction of LPS is given. On this basis, a qualitative approach to analyze and structure lean production system principles is given. This transfer shows that the use of the lean production system principles and methods is appropriate for the customer service.

Nevertheless, in this field of research a lot more research has to be done. For example, a methodical set of rules, only described qualitatively in this paper, has to be developed for OEMs offering after sales services. This includes the identification of further appropriate principles not considered in this paper. To develop this guide line, the execution of a detailed process analysis of the different task areas in customer services is needed. For an individual implementation, an implementation process has to be defined, similar to the LPS implementation process [26].

Moreover, concrete effects and benefits of the lean transfer to customer service have to be examined so that valid conclusions about improvement in efficiency can be made. Nonetheless, implementing and using LPS principles in customer service is a possibility for OEMs to enlarge their margins and increase customer satisfaction and loyalty so that this business unit will still be an effective sector for manufacturing companies.

\section{References}

1. Zeithaml, V.Z.; Bitner, M.J; Gremler, D.D.: Services marketing - Integrating customer focus across the firm. Mc-Graw-Hill, New York (2013)

2. Kastalli, I.V.; Van Looy, B.: Servitization: Disentangling the impact of service business model innovation on manufacturing firm performance. Journal of Operations Management (Volume 31, Number 4), pp.169-180 (2013)

3. Mahmoodzadeh, E.; Jalalinia, S.; Yazdi, F.N.: A business process outsourcing framework based on business process management and knowledge management. Business Process Management Journal (Volume 5, Number 6), pp. 845-864 (2009)

4. Neely, A.: Exploring the financial consequences of the servitization of manufacturing. Operations Management Research (Volume 1, Number 2), pp. 103-118 (2008)

5. Roland Berger Strategy Consultants: think:act content - Evolution of service (2013)

6. Dombrowski, U.; Schulze, S.; Engel, C.: Zukunftsgerechte Gestaltung des After Sales Service. ZWF 106 (Issue 5), pp. 366-371 (2011)

7. Allway, M.; Corbett, S.: Shifting to Lean Service: Stealing a Page from Manufacturers' Playbooks. Journal of Organizational Excellence, spring, pp. 45-54 (2002) 
8. Qi, J.-Y.; Zhou, Y.-P.; Chen, W.-J.; Qu, Q.-X.: Are customer satisfaction and customer loyalty drivers of customer lifetime value in mobile data services: a comparative cross-country study. Information Technology and Management (Volume 13, Issue 4), pp. 281-296 (2012)

9. Turunen, T.T.; Toivonen, M.: Organizing customer-oriented service business in manufacturing. Operations Management Research (Volume 4, Issue 1-2) pp.74-84 (2011)

10. Saccani, N.; Johansson, P.; Perona, M.: Configuring the after-sales service supply chain: A multiple case study. International Journal of Production Economics (Volume 110, Issue 12), pp. 52-69 (2007)

11. Wang, G.; Wang, J.; Ma, X.; Qiu, R.G.: The Effect of Standardization and Customization on Service Satisfaction. Journal of Service Science (Volume 2, Issue 1), pp. 1-23 (2010)

12. Dombrowski, U.; Winnefeld, M.: After Sales Service - Trends und Lösungsansätze - Ergebnisse einer Studie. Shaker Verlag, Aachen (2012)

13. Hoppmann, J.; Rebentisch, E.; Dombrowski, U.; Zahn, T.: A Framework for Organizing Lean Product Development. Engineering Management Journal (Volume 23, Number 1), pp. 3-15 (2011)

14. Dombrowski, U.; Ebentreich, K.; Schmidtchen, K.: Systematic approach to adopt LPS principles in product development. Proceedings of 22nd International Conference on flexible Automation and Intelligent Manufacturing, pp. 901-908 (2011)

15. Korge, A.; Lentes, H.-P.:Ganzheitliche Produktionssysteme - Konzepte, Methoden, Erfolgsfaktoren. In: Bullinger, H.-J.; Spath, D.: Wernecke, H.J. Westkämper, E.: Handbuch Unternehmensorganisation. Springer Verlag, Berlin, pp. 569-574 (2009)

16. VDI - Verein Deutscher Ingenieure: Lean production systems - Basic principles, introduction, and review. Beuth Verlag GmbH, Berlin (2012)

17. Spath, D.: Revolution durch Evolution. In: Spath, D.: Ganzheitlich produzieren - Innovative Organisation und Führung. LOG_X Verlag, Stuttgart (2003)

18. Song, W.; Tan, K.H.; Baranek, A.: Effective toolbox for lean service implementation. International Journal of Service and Standards (Volume 5, Number 1), pp. 1-16 (2009)

19. Wesemann, S.: Ganzheitliches Krankenhaussystem (GKS) - Ein Organisationsmodell für Krankenhäuser. Shaker Verlag, Aachen (2014)

20. Laqua, I.: Lean Administration. ZWF 100 (Issue 12), pp. 738-742 (2005)

21. Johansson, P.; Olhager, J.: Industrial service profiling: Matching service offering and process. International Journal of Production Economics (Volume 89, Issue 3), pp. 309-320 (2004)

22. Brunt, D.: Applying Lean to Dealers - After Sales Service. 2. German Conference "After Sales Service”, Frankfurt (2011)

23. Ohno, T.: Toyota Production System - Beyond Large-Scale Production. Productivity Press, New York (1988)

24. Imai, M.: Gemba Kaizen. McGraw-Hill, New York (1997)

25. Dombrowski, U.; Schmidt, S.: Framework for the Planning and Control of Lean Production System Implementation. International Journal on Agile Manufacturing, pp. 146-151 (2008)

26. Dombrowski, U.; Schmidt, S.; Crespo I.: Knowledge Management as a Supporting Function in Lean Production System Implementation. Proceedings of the 2nd International Conference on Changeable, Agile, Reconfigurable and Virtual Production (CARV), pp. 453-462 (2007) 